\title{
Research on Legal System for Prevention and Control of Agricultural Non-Point Source Pollution
}

\author{
Pengtao Wang \\ Department of Ideological and Political Theory \\ Agriculture Science And Technology College \\ Chuangchun, China \\ E-mail: kingmesh@126.com
}

\author{
Zhe Yu \\ Jilin Public Transport Technical School \\ Chuangchun, China \\ E-mail: automesh@163.com
}

\begin{abstract}
Agricultural non-point source pollution together with the industrial revolution are growing by leaps and bounds in more than 300 years long, and with the continuously follow of pollution treatment technology, related systems and right financial input, then gradually decrease and stable. However, human beings fight against pollution can not have a moment to respite. There are only decades since the beginning of agricultural green revolution in the $1950 \mathrm{~s}$, though agricultural source pollution problem is intensified, and it makes human cannot live healthy and happily in the long run. On the one hand, the agriculture and source along with the development of the petrochemical stone agricultural pollution and the traditional point source to get effective governance and becomes the important source of water pollution; On the other hand, agricultural stakeholders including government did not take a fancy as "spring", they only focus on the "summer" and "autumn", which is high yield, the agricultural income growth. So "double revolution" which is the revolution of environmental protection and agricultural production, is urgently needed in agriculture revolution, and only this can resolve the problems of the above two aspects. In any modern country, a good environmental protection laws can be find, but it is hard to find good agricultural non-point source pollution prevention. Almost any field (social science and natural science), there is no shortage of literature about agricultural non-point source pollution, but this issue is just getting started in law field. From the above, this article tries to research on legal system to prevent and control agricultural non-point source pollution.
\end{abstract}

Keywords-point source pollution; agricultural non-point source pollution; double green revolution; system consummation

\section{INTRODUCTION}

Prevention and control of agricultural non-point source pollution is a very challenging in the area of environment difficult problem. Compared with the control measures of point source pollution research, research of agricultural non-point source pollution is also quite limited and weak even in developed countries. The reason is that the characteristics of agricultural non-point source pollution make it complicate policies and measures. Agricultural non-point source pollution highly fragmented sources makes its emissions have the characters of considerable uncertainty, compared with point source pollution. According to the current monitoring technology, the managers are hard to be performed within the reasonable cost effective and precise measurement, thus unable to determine who should be responsible for the agricultural non-point source pollution, and each subject of agricultural non-point source pollution (small farms, small and scattered farmers) shall bear how much of responsibility, which make the policy tool failure based on emissions, the economists generally advocated lose efficacy.

\section{Agricultural Non-Point Source Pollution Acts AS AN IMPORTANT SOURCE OF WATER POLLUTION}

Agricultural non-point source pollution can be understood in three aspects: firstly, it is a kind of non-point source pollution; secondly, it is a source of agricultural pollution; finally, it is a kind of pollution against water. Agricultural nonpoint source pollution is defined as: trophoplasm, toxic substances, bacteria, such as crop residues generate in agricultural production activity caused by the pollution of water environment, and the pollutants are from a wide range or large area, provides by the surface runoff, soil, irrigation and drainage on dispersion into the earth's surface or underground water body.

Many toxic elements and compounds exist in sewage, and wastewater irrigation usually brings serious groundwater pollution. Israel created the modern water-saving agriculture, and $75 \%$ of the recycle waste water is used in agriculture, and $40 \%$ of the farmland within the borders using after purification of wastewater to irrigate. But according to a survey published by Israel's water conservancy department and the nature and the parks department, although recycle wastewater after sewage is processed in purification treatment, however except clean water treated by Israel's largest Shafdan wastewater treatment plants, the rest of the outflow of water purification which the content of pollutants is still not up to European standards. The purification of the waste water infiltrates into underground water by agricultural use, and there are annually 145000 tons into the agricultural water salinity aquifer. And the nitrogen content on the high side after test agricultural use appropriative water storage tank, which is also the main components of the drinking water pollution. 


\section{THE MAIN CHARACTERISTICS OF AGRICUlTURAL NON- POINT SOURCE POLLUTION AND THE DIFFICULTY IN} PREVENTION AND CONTROL

The characteristic of the agricultural non-point source pollution of "face" refers to the placing signage at the agricultural non-point source pollution on the spatial distribution of dispersion. Points can constitute a line, also can form surface, a "face" is actually composed of many "points". Agricultural non-point source made up of many scattered, concrete placing signage at the little pollution, the many small point source distribution in a relatively forming on the surface (river basin or region) of a single point source pollutant release is the "trace", but a wide range of point source under the action of various factors, aggregated into a source of "face", its pollutant emissions and pollution degree is enough to cause attention.

Compared with the point source pollution, the agricultural non-point source pollution emissions monitoring is extremely difficult. First of all, the height of the agricultural non-point source pollution dispersion caused the difficultly to monitor. Generally a single point source pollution sources happened in determining the location; however Agricultural non-point source pollution is not a single source of pollution, and any piece of land is likely to release pollutants, the general areas of pollutants in the precipitation of factors such as react with each other under the action of cross, overlapping, and eventually into the target water, so it is difficult to identify the concrete placing signage at of pollutants. Specific geographical boundaries of agricultural non-point source pollution source and the space position is not easy to identify, and only be considered on a relatively "face". Pollution position is extremely uncertain, which is difficult to monitor the pollution emission. Secondly, the randomness and instability of the agricultural non-point source pollution emissions caused difficultly of monitor. Non-point pollution emissions less affected by natural factors, general continuous and stable. The occurrence of agricultural non-point source pollution due to weather conditions, the hydrological cycle, ground vegetation conditions, such as the geological structure of different has spatial difference and the in homogeneity of the time. Agricultural non-point source pollution emissions in the vast ground on and off can happen anytime and anywhere, and different regions, different seasons in the same area and different years. Above all caused its effective regulation is difficult, high cost, and even impossible. How to effectively conduct surveillance on agricultural non-point source pollution emissions is still a problem in the theory and practice.

\section{EXPLORE AND TRY ON AGRICULTURAL NON-POINT SOURCE POLLUTION PREVENTION AND CONTROL OF THE CONSTRUCTION OF LEGAL SYSTEM}

Agricultural non-point source pollution phenomenon already exists, and it as a pollution problem be temporarily ignored because the concentration of industrial point source pollution emissions than the obvious hazards caused by the strength. Once identified, discovered the agricultural non-point source pollution, the government and legislative must respond.

\section{A. The Management System of Chemical Fertilizer and Pesticide}

In view of the improper application of fertilizers and pesticides is an important cause of agricultural non-point source pollution. So many countries did control and guidance in production, sale and use of fertilizers and pesticides from the transformation of environmental aspects. Rules on the legislation of fertilizers and pesticides are general rules of fertilizers and pesticides registration system, identification system and the corresponding supervision and inspection and punishment system, and limit fertilizer not according with standard and production, sales and application of high toxicity. Those relevant legal systems played an indirect effect on prevention and control of agricultural non-point source pollution.

\section{B. The Environment Tax System}

The environment tax regarded as "all mandatory, related to the environment by the government to impose tax" by OECD. According to this definition, the environment tax not only contains the harmful products directly to the environment and the behavior of tax revenue, also contains the environmental impact of indirect taxation, which the initial design may not consider environmental factors, but to achieve other purposes). Reasons of using environmental taxes are as below. Firstly, the environment tax is the effective measure to make the behavior of the internalization of external effect, and helps to implement the polluter pays principle. Second, the environment tax can change the behavior of producers and consumers, and promote the technological innovation. Thirdly, environmental tax can increase revenues to improve the environment. Finally, the environment tax is the most effective policy tool to solve the problem of pollution. Precisely because the environment tax has the advantage of this theory, so the environment tax system gets more and more attention both at home and abroad. Some people even think that "tax means to deal with environmental problems is the most perfect social regulation measures. Because the social costs of tax externality can be transferred to personal cost of production." In the practice, an environmental tax has been regarded as command "supplementary" measures of controlling means. Between drainage duty and product tax what to choose depends on two factors: one is whether there is a direct between goods and pollution emissions, stability. The other is the cost of monitoring the pollution emissions and its feasibility.

\section{THE LEGAL SYSTEM CONSTRUCTION AND THE INSUFFICIENCY OF PREVENTION AND CONTROL OF Agricultural Non-Point SOURCE POLLUTION IN OUR COUNTRY}

Collecting and sorting foreign system is for use at home. In US and Europe, the prevention and control of agricultural nonpoint source pollution in the water pollution prevention law provides for clear and specific coping mechanisms so that agricultural non-point source pollution control has a certain improvement. In the current legal system in our country, what kind of response for prevention and control of agricultural nonpoint source pollution? How about these strategies for prevention and control of agricultural non-point source 
pollution and what effect we received? This chapter is intended to clear these problems and find problems, so we do not pursue describe the outline of the legislation, but from the comparative study angle of to study some typical system.

The prevention and control system of agricultural non-point source pollution in water pollution control law.

\section{A. General Provisions}

1) The system of government environmental responsibility

2) The water quality standard, the water environmental quality monitoring and water environment unified information release system

3) The system of public participation

4) The present situation and the practice effect evaluation of agricultural non-point source pollution control system

From the perspectives of the system construction, the "law on the prevention and control of water pollution" and various kinds of regulations on prevention and control of agricultural non-point source pollution referring to legal norms have already adopted a system of measures to overcome the agricultural non-point source pollution control problems. This section will discuss the practice effect of system measures.

In the modern country under the rule of law, the legal system is the basis of behavior and management and framework, and where is the center of gravity to the legal system, the strengthen law enforcement efforts will be there, same as corresponding improvement. "Law on the prevention and control of water pollution" too fond of point source pollution, which leads to the governments' center of gravity still put at water pollution prevention and control, let agricultural non-point source pollution control be. Some local government on agricultural non-point source pollution has taken some measures, which out of agricultural non-point source pollution has affected the industrialization and urbanization considering the prevention and control of agricultural non-point source pollution. It is often after industrialization and urbanization a sequence of thought. Other legislation has made some provisions on the agricultural nonpoint source pollution prevention, but the legislation is not for prevention and control of water pollution, in the core purpose directly. So the provisions relating to the prevention and control of agricultural non-point source pollution most ambiguous, just mention with sex, lack of relevant supporting measures and poor maneuverability. Overall, China's current system has not been formed complete system of agricultural non-point source pollution prevention and control system, and system supply make the complex refractory problem for prevention and control of agricultural non-point source. At present, the water pollution is very serious, which problem from local river water pollution incident has extended to the area and basin, from a single development to the compound pollution, pollution from surface water to the groundwater pollution occur frequently. Water pollution is serious threat to water environment quality safety and public health, which has become China's current the most serious, the most pressing problem. To comprehensively resolve our country's water crisis, we must from the two aspects of water saving and prevent the degradation of water quality comprehensive consideration, the prevention and control of water pollution caused by the water quality of water; To fundamentally solve the problem of water pollution in our country, water saving and to prevent water quality degradation must take in the environmental protection legislation of agricultural non-point source pollution prevention and control into the important agenda, and build the system of agricultural non-point source pollution prevention and control system.

\section{CONSUMATE THE IMAGINE OF OUR COUNTRY Agricultural Non-Point Source Pollution PreVEntion AND CONTROL SYSTEM}

In the modern state which governance according to law, the legislative quality determines the quality of the rule of law, and lack of legislation is a basic key factors lead to practical difficulties.

"Prevention first, prevention and treatment integrated and comprehensive treatment" is "the law on the prevention and control of water pollution" in our country, and also the general principles of the environmental protection law in our country. Basing on this and combining with the analysis of the characteristics of agricultural non-point source pollution, foreign related systems and measures of comb and the review of relevant legal system in our country, this paper holds that our country can revolve around the following aspects of agricultural non-point source prevention and control of the system construction.

\section{A. Plan first in Prevention and Control of Agricultural Non- Point Source Pollution,}

Quite a number of local governments in the environmental protection is still not do "laws to go by, the laws must be observed and strictly enforced, and lawbreakers must be prosecuted "in Practice under the condition of the laws. Because the directly legislation on agricultural non-point source pollution in our country at present thin, many local governments are inadvertently overlooked the due responsibilities for controlling agricultural non-point source pollution. Agricultural non-point source pollution problem increasingly serious reality tells us that if the government the agricultural non-point source pollution do not valued, not completely improve water environment and water security, not only the safety of drinking water won't be completely guaranteed, even the sustainable development of the economy will eventually difficult to achieve because of the unsustainable development of human beings.

\section{B. The Preventive System of Agricultural Non-Point Source Pollution}

The management to reduce emissions.

1) Agricultural chemicals' management

2) To levy on duties of chemical fertilizers and pesticides

3) The agricultural environment subsidies

4) Agricultural cleaner production a) To reduce emissions of agricultural structure 
b) The synthesis of management reduction, structural reduction, which is the best agricultural management practices

\section{The governance system of agricultural non-point source pollution}

1) To list agricultural non-point source into water pollutant total amount control plan

2) To build of monitoring system construction of agricultural non-point source pollution

3) To integrate of water yield and water quality, surface water and groundwater management by watershed scale,

4) Special operation for key problem

5) The emergency response for agricultural non-point source pollution.

\section{CONCLUSION}

Ecological law "Matter related law" tell us that thing in nature between the mutual connection and restriction, interdependent relationship. And one of the things' changes is bound to be direct or indirect influence on other things. The agricultural non-point source pollution problem is increasingly serious. In fact, it is the outcome of human taking the agricultural industry, and agricultural land caused by excess development causing widespread damage to vegetation, wetland, and further intensify the agricultural non-point source pollution and difficulty of treatment.

"Load of ecological law norm law" tell us that any ecosystem has an approximate load (bear) ability limit, including certain ability to absorb pollutants, bear a certain degree of external shocks. If more than the limit loads capacity, the ecological system will be polluted and destructed. The production of agricultural non-point source pollution problem is because the human input too many chemicals to natural and those are beyond the capacity of land and water.

All sorts of environmental problems today humans encountered are mostly by human activities beyond the bearing capacity of natural. In fact, environmental crisis is extreme crisis. Human takes environment as a resource to develop and utilize. The environment only is valued when it hindered the pace of further use for human, and then problems of environment are appeared. In fact, environmental didn't do anything. If the environment can speak, it would have said that mankind has a problem. Now the most need to do is to reflect behaviors on own human, study, respect and use ecological laws, and behavior moderately in the framework of law. This is the source of pollution prevention control.

This paper proposed a variety of the regulation measures of prevention and control of agricultural non-point source pollution, and of which is better, it is to be further in-depth study by practice research remains. Weinberger pointed out that specification and value cannot be established on a purely cognitive way, and composition system of rules is not a priori facts but artificial facts.

\section{REFERENCES}

[1] William L.Andreen, Water Quality Today-Has the Clean Water Act been a Success?,Alabama Law Review,Spring 2004.

[2] William L. Andreen: The Evolution of Water Pollution Control in the United States-State, Local, and Federal Effort, 1789-1972: Part II, Standord Evnironmental Law Journal, June, 2003.

[3] Kenneth M. Murchison: Learning from More Than Five-And-A-Half Decades of Federal Water Pollution Control Legislation: Twenty Lessons for the Future, Boston College Environmental Affairs Law Review, 2005.

[4] Richard B. Stewart: A New Generation of Environmental Regulation, Capital University Law Review, Vol 29, 2001.

[5] Robert W. Adler, The Two Lost Books in the Water Quality Trilogy: The Elusive Objectives of Physical and Biological Integrity, Environmental Law, Vol 33,2003. 